\title{
LOCALIZED UNRESECTABLE PANCREATIC CANCER TREATED WITH HIGH ENERGY NEUTRONS AND CHEMOTHERAPY AT FERMILAB - PRELIMINARY RESULTS
}

\author{
K. R. Saroja, M.D. ${ }^{1}$, L. Cohen, M.D. ${ }^{2}$, F. R. Hendrickson, M.D. ${ }^{1}$, JoAnne Mansell, R.N.,P.A.,O.C.N. ${ }^{3}$ \\ ${ }^{1}$ Rush Presbyterian St. Luke's Hospital, Radiation Therapy Department, Chicago, Il 60612 \\ ${ }^{2}$ Michael Reese Hospital/University of Chicago, Radiation Therapy Department, Chicago, IIL 60637 \\ ${ }^{3}$ Fermi National Accelerator Laboratory, Neutron Therapy Facility, Batavia, IL 60510
}

\begin{abstract}
Between January 1985 and July 1989 a total of thirty-eight patients with locally advanced pancreatic cancer were treated with high energy neutrons at Fermilab. Twenty-one patients received only neutrons and seventeen were given chemotherapy in addition, either concurrently or subsequently following the completion of neutron irradiation. This is a retrospective study. Data were analyzed for tolerance, complications and survival. Three of the twenty-one (14\%) patients who received only neutron beam therapy developed Grade III or greater complications in the RTOG/EORTC scale. The median survival was 6.4 months. One of these patients is alive 10 months post treatment. Of seventeen patients who also received chemotherapy, five (29\%) had severe complications. However, median survival was 13.5 months. Four of these seventeen patients are still alive at the time of this analysis.

The preliminary results show that there is improvement in the survival of patients treated with combined neutron irradiation and chemotherapy. A pilot study to further evaluate these results in a larger group of patients is underway. Details of complications and chemotherapy regimen will be presented.
\end{abstract}

\section{Introduction}

Cancer of the pancreas is the second most common malignancy of the gastrointestinal tract and the fifth leading cause of cancer death in the United States.

Cure of pancreas cancer is uncommon. If the tumor is resectable by radical surgery, (Whipple procedure), the 5 year survival rate is $15 \%$. However, in most patients the disease has extended beyond the pancreas at the time of diagnosis and hence it is unresectable.

Various approaches to manage locally advanced pancreatic cancer include high dose external photon irradiation with or without chemotherapy, intensive local irradiation with intraoperative electron beam therapy or ${ }^{125}$ radioactive seed implants, and use of high LET particles (neutrons and heavy ions) with or without chemotherapy. All have yielded consistently low long term survival. High energy fast neutron beam therapy is used at Fermilab to treat patients with unresectable carcinoma of the pancreas. We are reporting the preliminary results of a retrospective analysis of these groups of patients treated between January 1985 and July 1989.

\section{Materials and Methods}

A total of 38 patients with unresectable carcinoma of the pancreas were treated using high energy fast neutrons at Fermilab Neutron Therapy Facility in Batavia, IL between January 1985 and July 1989. Twenty-one of these 38 patients received only neutron beam therapy and seventeen patients were given chemotherapy in addition. The treatment planning for external neutron beam therapy involved a three field technique and the use of wedges to obtain a uniform dose distribution (figure 1) with minimal dose to the kidneys and spinal cord. The target absorbed dose prescribed was 18 Gy delivered in 12 fractions, 3 fractions/week over 4 weeks. 
The single or multiagent chemotherapy administration was done either concurrently or 2-4 weeks subsequent to completion of neutron beam therapy. Most patients received 5FU as a bolus. Chemotherapy agents and doses used were determined by medical oncologists. The chemotherapy was administered with the first 3 and the last 3 neutron fractions. On a few occasions the latter course had to be withheld due to poor patient tolerance. Blood counts were monitored closely in all 38 patients. The treatment-related acute side effects were managed symptomatically. The number of patients and tumor characteristics are shown in Table 1.

\section{Results}

The results were analyzed for treatment-related morbidity and survival. Table 2 shows treatmentrelated side effects in both groups. These occurred in 2 of $21(10 \%)$ patients in the neutron therapy group and in 7 of $17(41 \%)$ patients in the combined modality group. The other acute effects included nausea, vomiting, occasional diarrhea, and these were managed symptomatically.

Late normal tissue complications were graded according to RTOG/EORTC. Three patients (14\%) who were treated with neutrons only and 5 of $17(29 \%)$ patients who received chemotherapy and neutrons developed Grade 3 or greater complications. The details are shown in Table 3. The late morbidity could probably be reduced or modified by using single agent ( $5 F \mathrm{~W}, 500 \mathrm{mg} \mathrm{per} \mathrm{m}^{2}$ ) rather than multiagent chemotherapy regimen. The calculation of survival was made from the first treatment day. The survival curve for both groups is depicted in Figure 2. The median survival was 6.4 months for patients with neutrons and 13.5 months for the group with combined chemotherapy and neutrons. One patient is alive and well 10 months post neutron therapy. There are 3 patients alive to date in the combined neutron and chemotherapy group. These are 5 years, 3 years, and 21 months post treatment respectively. 
Table 1

\begin{tabular}{|c|c|c|}
\hline \multicolumn{3}{|c|}{ Carcinoma of the Pancreas - Patient Characteristics } \\
\hline & Neutrons Only & Neutrons \& Chemo \\
\hline Number of Patients & & \\
\hline $\begin{array}{c}\text { Males } \\
\text { Females } \\
\text { Ages in Years }\end{array}$ & $\begin{array}{r}12 \\
9\end{array}$ & $\begin{array}{r}10 \\
7\end{array}$ \\
\hline $\begin{array}{c}\text { Range } \\
\text { Median } \\
\text { Tumor Characteristics }\end{array}$ & $\begin{array}{l}48-84 \\
68\end{array}$ & $\begin{array}{l}43-76 \\
57\end{array}$ \\
\hline $\begin{array}{ll} & \text { Primary } \\
\text { Recurrent } \\
\text { Head of Pancreas } \\
\text { Body and/or Tail } \\
\text { Ampulla } \\
\text { Pathology - Adenocarcinoma } \\
\text { Other } \\
\text { Diagnosis }\end{array}$ & $\begin{array}{r}21 \\
0 \\
0 \\
15 \\
5 \\
1 \\
21 \\
0\end{array}$ & $\begin{array}{r}16 \\
1 \\
16 \\
1 \\
0 \\
17 \\
0\end{array}$ \\
\hline $\begin{array}{l}\text { Needle biopsy only } \\
\text { Exploratory laparotomy \& } \\
\text { bypass surgery }\end{array}$ & $\begin{array}{r}7 \\
14\end{array}$ & $\begin{array}{r}5 \\
12\end{array}$ \\
\hline $\begin{array}{ll}\text { Neutron dose } \\
\text { Fractions } \\
\text { Time (Average) }\end{array}$ & $\begin{array}{l}18 \mathrm{~Gy} \\
12 \text { days } \\
30 \text { d }\end{array}$ & $\begin{array}{l}18 \mathrm{~Gy} \\
12 \text { days } \\
29 \text {. }\end{array}$ \\
\hline
\end{tabular}


Table 2

\section{Carcinoma of the Pancreas - Treatment - Related Morbidity}

\begin{tabular}{|l|c|c|}
\hline Type of Morbidity & Neutrons Only & Neutrons \& Chemo \\
\hline Acute (90 days or less) & & \\
\hline \multicolumn{1}{|c|}{ Leukopenia } & None & $\begin{array}{c}\text { 2 patients } \\
\text { (1 developed sepsis) }\end{array}$ \\
\hline \multicolumn{1}{|c|}{ Range } & & $1-18 \%$ \\
$\quad$ Mean & $1-12 \%$ & $9 \%$ \\
GI bleeding - Required & $6 \%$ & \\
blood Transfusion & 1 patient-Due to tumor \\
Hospitalization for IV fluids, & erosion of duodenum \\
electrolytes and/or hyper- & 1 patient & 5 patients (1 patient \\
alimentation & had exacerbation \\
\hline TOTAL(Acute) & of known peptic ulcer & \\
\hline
\end{tabular}

\begin{tabular}{|l|l|}
\hline Late Effects (90 days or more & post-treatment) \\
\hline
\end{tabular}

Thrombocytopaenia

Gastric ulcer on endoscopy

Radiation fibrosis of

duodenum requiring

surgery

Hemorrhagic gastritis

Sepsis

TOTAL (Late)
1 (tumor related)

1

1 (1 yr post tx)

Had bleeding of

duodenal ulcer

0

0

1 5 
Table 3

Details of Morbidity in Neutrons and Chemotherapy Group (5 Patients)

\begin{tabular}{|c|c|c|c|c|}
\hline $\begin{array}{l}\text { Patient } \\
\text { I.D. \# }\end{array}$ & $\begin{array}{c}\text { Type of } \\
\text { Chemotherapy }\end{array}$ & $\begin{array}{c}\text { Time of } \\
\text { Chemotherapy }\end{array}$ & $\begin{array}{c}\text { Type of Morbidity } \\
\text { (Onset) }\end{array}$ & Remarks \\
\hline 87-019 & $5 F U$ & Concurrent & $\begin{array}{l}\text { Hemorrhagic } \\
\text { gastritis } \\
\text { (1 year post tx) }\end{array}$ & $\begin{array}{l}\text { Alive } 3 \text { years - } \\
\text { Has caecal mets }\end{array}$ \\
\hline $87-099$ & $\begin{array}{c}5 F U \& \\
\text { Mitomycin }\end{array}$ & Concurrent & $\begin{array}{l}\text { Cholangitis } \\
\text { (3-4 months) }\end{array}$ & $\begin{array}{l}\text { Had surgery for } \\
\text { stricture at } \\
\text { G.J. anastomotic } \\
\text { site. Expired. }\end{array}$ \\
\hline $88-088$ & $\begin{array}{l}5 \text { FU followed } \\
\text { by FAM }\end{array}$ & Concurrent & $\begin{array}{c}\text { Hemorrhagic } \\
\text { gastritis } \\
\text { (5 months) }\end{array}$ & $\begin{array}{l}\text { Expired } 21 \text { months } \\
\text { post tx. Developed } \\
\text { distant mets. }\end{array}$ \\
\hline 88-089 & $\begin{array}{c}\text { 5FU \& } \\
\text { Adriamycin }\end{array}$ & Subsequent & $\begin{array}{c}\text { Hemorrhagic } \\
\text { gastritis } \\
\text { ( } 5 \text { months })\end{array}$ & $\begin{array}{l}\text { Had gastrectomy } \\
\text { for persistent } \\
\text { bleeding. Died of } \\
\text { sepsis. }\end{array}$ \\
\hline 89-004 & $\begin{array}{l}5 F U \text { only } \\
\text { for } 6 \text { months }\end{array}$ & Subsequent & $\begin{array}{l}\text { Exacerbation of } \\
\text { known peptic } \\
\text { ulcer disease } \\
\text { with minimal } \\
\text { bleeding } \\
\text { (4 months) }\end{array}$ & $\begin{array}{l}\text { Alive and well } \\
21 \text { months post tx. } \\
\text { CT scan shows } \\
\text { resolution of local } \\
\text { disease }\end{array}$ \\
\hline
\end{tabular}

\section{Conclusions}

1. The combination of neutron beam irradiation and chemotherapy for patients with unresectable carcinoma of the pancreas is tolerated with an acceptable degree of morbidity.

2. There is improvement in the median survival of the group of patients treated with combined modality (13.5 versus 6.4 months).

3. There appears to be a long-term survival rate of about $18 \%$, commersuate with that of primary radical surgery.

4. Neutron irradiation with chemotherapy is a reasonable alternative to other modalities and has the special advantage of a much shorter overall treatment time. 
Figure 2

PANCREAS CA.: ACTUARIAL SURVIVAL CURVE

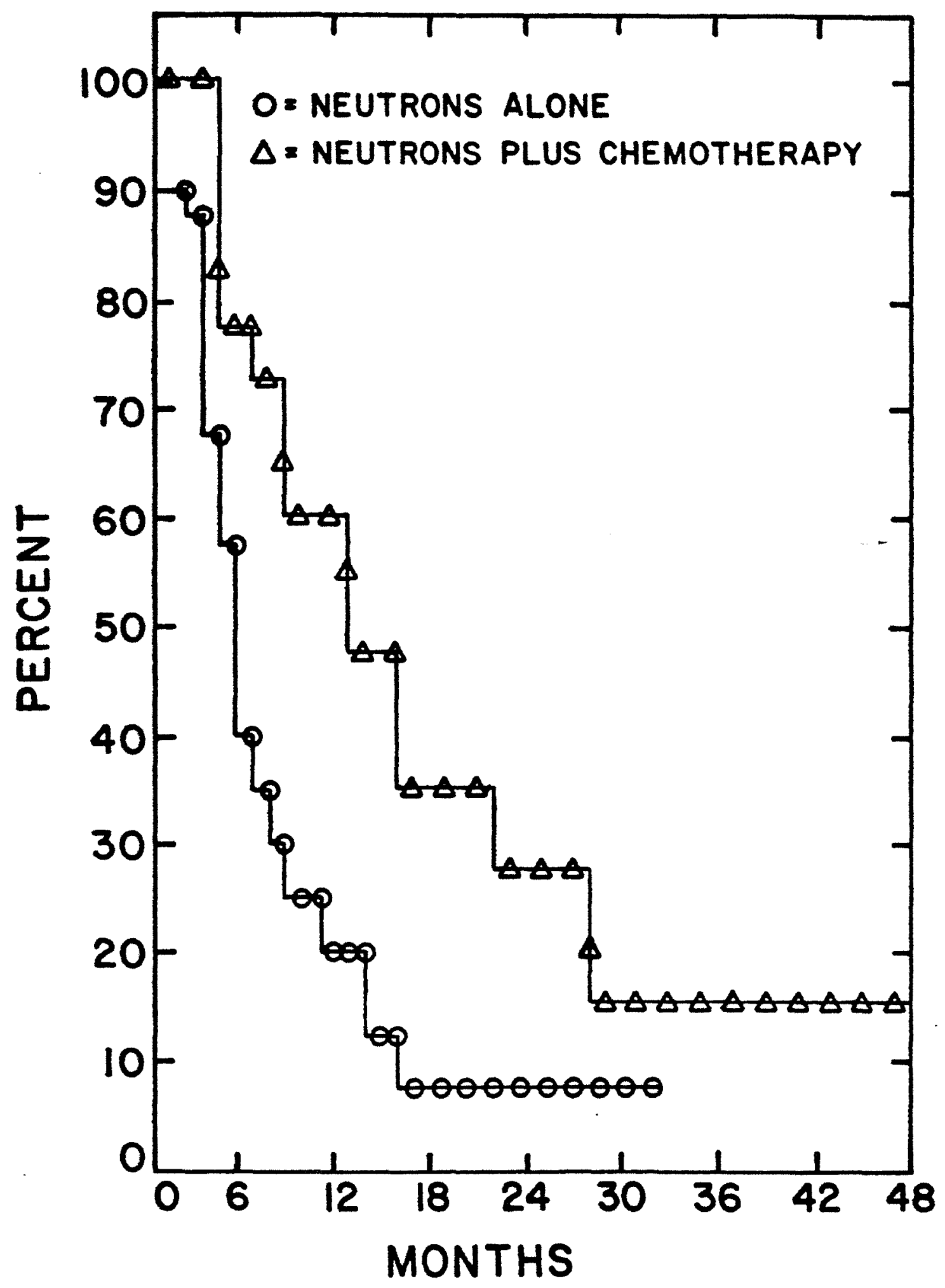

